\title{
Acute Respiratory Distress Syndrome Induced by White Smoke Inhalation: a Potential Animal Model For Evaluating Pathological Changes and Underlying Mechanisms
}

\author{
Pei Cuia Xiaoyan Feng ${ }^{b}$ Feng Zhuc ${ }^{c}$ Yongming Yao ${ }^{d}$ Shichu Xiaoc \\ Zhenyu Gong $^{\mathrm{b}}$ Haiming Xin ${ }^{\mathrm{b}}$ Qiu Zhan ${ }^{\mathrm{a}}$ Fuwang Yang ${ }^{\mathrm{b}}$ \\ Chunjiang Deng $^{\mathrm{a}} \quad$ Zhiping Tang ${ }^{\mathrm{a}}$ Yalin Tong ${ }^{\mathrm{a}, \mathrm{b}} \quad$ Zhaofan Xia $^{\mathrm{c}}$
}

${ }^{a}$ Research Laboratory of Burns and Trauma, the 181st Hospital of Chinese PLA, Guilin, bDepartment of Burns, Plastic and Wound repair surgery, the 181st Hospital of Chinese PLA, Guilin, 'Department of Burn surgery, Changhai Hospital, Naval Military Medical University, Shanghai, dTrauma Research Center, First Hospital Affiliated to the Chinese PLA Ceneral Hospital, Beijing, PR China

\section{Key Words}

White smoke inhalation $\cdot$ Acute respiratory distress syndrome $\cdot$ NF-kB $\bullet$ Therapeutic target $•$ Animal model

\begin{abstract}
Background/Aims: White smoke inhalation (WSI) is an uncommon but potentially deadly cause of acute respiratory distress syndrome (ARDS). However, no clinical treatment protocol has been established for the treatment of WSI-induced ARDS. Therefore, it is necessary to investigate the effects of WSI in ARDS and the mechanisms underlying the effects of WSI to determine a novel therapeutic target. Methods: On the basis of the duration of continued inhalation of white smoke ( $3 \mathrm{~min}, 5 \mathrm{~min}$, and $7 \mathrm{~min}$ ), rats were divided into three groups (WSI$3 \mathrm{~min}$, WSI-5 min, and WSI-7 min). The survival rate, pathological change, and computed tomography $(\mathrm{CT})$ score were evaluated to determine the modeling conditions. In the established WSI-5 min models, evaluations were performed to evaluate the following: arterial blood gas levels, lung wet/dry weight ratio, the expression of inflammatory cytokines, and the effect of NF-KB signaling pathway. Results: The survival rate of rats at $72 \mathrm{~h}$ post-WSI in the WSI-3 min, WSI-5 min, and WSI-7 min groups was $83.33 \%, 75 \%$, and $25 \%$, respectively. Results from evaluation of $\mathrm{H} \& \mathrm{E}$ staining, CT scan, arterial blood gas levels, and lung wet/dry weight ratio suggest that the pathological changes in the rat in the WSI-5 min and WSI-7 min groups are very similar to those in patients with ARDS induced by WSI. Additionally, the expression
\end{abstract}

Pei Cui and Xiaoyan Feng have contributed equally to the work described in this paper.

Yalin Tong

and Zhaofan Xia

KARGER
Department of Burns, Plastic and Wound Repair Surgery The 181st Hospital of Chinese PLA, Guilin 541002, (PR China) and Department of Burn surgery,

Changhai Hospital, Naval Military Medical University, Shanghai 200433, China.

E-Mail scsyj_sys@163.com / xiazhaofan_smmu@163.com 


\section{Cellular Physiology Cell Physiol Biochem 2018;47:2396-2406 \\ \begin{tabular}{l|l} 
DOI: 10.1159/000491614 & $\begin{array}{l}\text { O 2018 The Author(s). Published by S. Karger AG, Basel } \\
\text { www.karger.com/cpb }\end{array}$
\end{tabular} \\ Cui et al.: A Animal Model of Acute Respiratory Distress Syndrome Induced by White}

Smoke Inhalation

of INF- $\gamma$, TGF- $\beta 1$, TNF- $\alpha$, and IL-1 $\beta$ were increased, and the NF-KB signaling pathway was activated in the WSI- 5 min group. Conclusion: The rat model of WSI- 5 min can be used as a WSI-induced ALI model for further experiments. The NF-KB signaling pathway may be a potential therapeutic target for the treatment of WSI- induced ARDS.

(C) 2018 The Author(s)

Published by S. Karger AG, Basel

\section{Introduction}

Smoke pots, widely used in fire drills, can produce white smoke seconds after ignition, and the entire smoking time lasts for 6-7 min [1]. On exposure to high concentration of white smoke, especially in a confined space, white smoke is inhaled into the lung through the respiratory tract, which triggers inhalation injury [2], including acute lung injury (ALI), acute respiratory distress syndrome (ARDS) and pulmonary fibrosis, even leading to death [3-5]. However, no clinical treatment protocol has been established for the treatment of white smoke inhalation (WSI)-induced ARDS. Major components of the white smoke generated from a smoke pot include zinc chloride, hexachloroethane, oxides (zinc oxide, aluminum oxide, iron oxide, etc.), and carbon dust [6]. Additionally, some intermediate products, such as tetrachlorethylene, carbon tetrachloride, carbon monoxide, and carbon dioxide, are present mixed with the main components [7]. Cigarette smoking induces alveolar enlargement, endoplasmic reticulum stress, DNA damage, led to impairment of lung function $[8,9]$. The components of white smoke differ from the components of smoke generated by the combustion of tobacco or wood dust; the former, in addition to carbon and carbon oxides, also contains other highly corrosive, irritant and toxic substances, including halogenated hydrocarbons and zinc chloride, which increase the severity of inhalation injury [10]. In the past few decades, many studies have been reported on ARDS caused by the individual or combined components of white smoke including zinc chloride and hexachloroethane [11, 12]. However, the effects of all components of white smoke on ARDS, and the mechanisms underlying these effects, remain unclear.

Previous reports of ARDS caused by WSI were mainly based on analysis of clinical cases. Owing to the effects of the treatment, it is difficult to determine the pathophysiological changes and pathogenesis of ARDS caused by WSI. Therefore, an animal model of WSI-induced ALI is needed to understand the pathophysiological changes and pathogenesis of ARDS caused by WSI, which will aid in determining strategies for timely diagnosis and finding a novel therapeutic target for this condition. In this study, we explored the conditions for developing an animal model with WSI-induced ALI based on the survival rate for investigated the pathophysiological changes of ARDS caused by WSI. Furthermore, the effect of inflammatory cytokines and NF- $\kappa B$ signaling pathway on WSI-induced ALI model were evaluated.

\section{Materials and Methods}

\section{Preparation of experimental rats}

All animal protocols were approved by the ethics committee of the No. 181 Hospital of the People's Liberation Army (PLA) and the disposal methods followed animal ethics standards. Specific pathogenfree (SPF) male Sprague-Dawley (SD) rats weighing 200-220 g were used. All rats were purchased from the animal center of Guilin medical college. The rats were allowed free access to water and food and were maintained at $20-25^{\circ} \mathrm{C}$; the room was continuously ventilated, with 12 hours of illumination and 12 hours of darkness. The rats were adapted to the environment for 7 days before establishing the WSI model.

\section{Establishment of the WSI model}

The experimental steps for establishing the WSI model are shown in Fig. 1. First, rats were placed in a rat cage, with an isolation network to separate each rat, so that the impact of white smoke could be observed individually. Then, the rat cage was placed in the center of the 2- $\mathrm{m}^{2}$ homemade laboratory equipment that is used for research on smoke-induced injury (Patent No.: 201720002689.0), and the smoke pot was 


\section{Cellular Physiology Cell Physiol Biochem 2018;47:2396-2406 \\ \begin{tabular}{l|l|l} 
DOI: 10.1159/000491614 & O 2018 The Author(s). Published by S. Karger AG, Basel \\
www.karger.com/cpb
\end{tabular}}

Cui et al.: A Animal Model of Acute Respiratory Distress Syndrome Induced by White

Smoke Inhalation

located $60 \mathrm{~cm}$ below the rat cage. Additionally, the smoke pot was ignited and allowed to burn, and it gradually produced smoke. The duration of WSI (WSI-time) was calculated from the beginning of smoke generation. After WSI, the rats were fed under normal conditions as described in 2.1.

\section{Experimental groups}

Thirty-six rats were divided

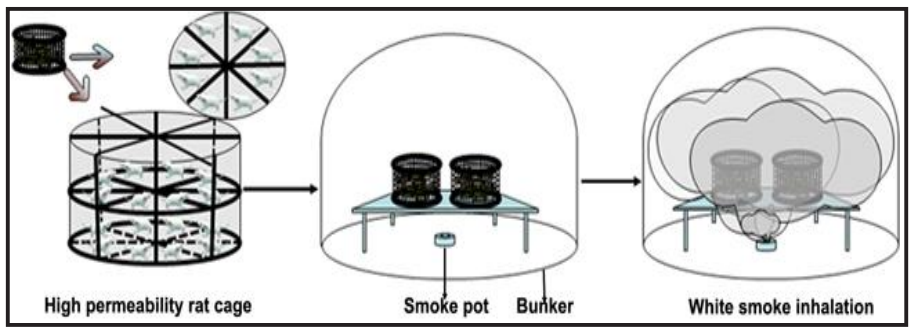

Fig. 1. Schematic of the establishment white smoke inhalation (WSI) model.

into 3 groups randomly: WSI-3 min group (WSI-time was 3 mins); WSI-5 min group (WSI-time was 5 mins); and WSI-7 min group (WSI-time was $7 \mathrm{mins}$ ). The survival rate of the rats was observed at $24 \mathrm{~h}, 48 \mathrm{~h}$, and $72 \mathrm{~h}$ post-WSI to screen the modeling conditions. Then, rats induced by WSI were observed at $6 \mathrm{~h}, 12 \mathrm{~h}, 24$ $\mathrm{h}, 48 \mathrm{~h}$, and $72 \mathrm{~h}$ post-WSI.

\section{Histomorphological features of the lung tissues}

The histomorphological features of the lung tissues were evaluated by hematoxylin and eosin (H\&E) staining. The diaphragmatic leaves of the right lung from rats in each group were fixed with $4 \%$ formalin for $48 \mathrm{~h}$, washed, dehydrated, hardened, cleared, and infiltrated with wax; the samples were then embedded in paraffin, and 4- $\mu \mathrm{m}$ sections were obtained. Hematoxylin and eosin (H\&E) staining was performed according to the manufacturers' instructions (Solarbio, Beijing, China). Histomorphological features of the lung tissues were observed under an optical microscope (Olympus, Japan). The degree of lung injury was graded as described previously [13].

\section{CT Scan evaluation}

Rats were fixed to a foam board in supine position under general anesthesia using chloral hydrate. Then, rat breast was scan was performed by a GE LightSpeed VCT (GE Healthcare, Little Chalfont, UK) 64-slice CT at $80 \mathrm{kV}$ tube voltage, $150 \mathrm{~mA}$ tube current, and medium bowtie filter (0.625-mm half-value layer). CT images were scored according to the Radiologist's score (RADS) method as previously described [14].

\section{Analysis of arterial blood gas levels}

One-mL of anti-coagulated blood sample was collected from the abdominal aorta of each rat. Then, the $\mathrm{PaO}_{2}, \mathrm{PaCO}_{2}$, and $\mathrm{PaO}_{2} / \mathrm{FiO}_{2}$ were analyzed by blood gas analyzer (Radiometer, Denmark).

\section{Wet/dry weight ratio}

After anesthetic overdose and exsanguination (by severing of the inferior vena cava and the abdomen aorta), all the excised lung lobes per mouse were weighed (wet weight), placed in an oven and weighed daily until its weight unchanged (dry weight). The wet/dry weight ratio was then calculated.

\section{Inflammatory cytokines were measured by ELISA}

In each rat, the right lung was removed followed by ligation of the right main bronchus. Injection of 1 $\mathrm{ml}$ of iced saline from the end of the trachea was performed, and the lavage was repeated three times. Then, $2.6 \mathrm{ml}$ of bronchoalveolar lavage fluid was collected and centrifuged at $350 \mathrm{~g}$ for $10 \mathrm{~min}$ at $4{ }^{\circ} \mathrm{C}$. TGF- $\beta 1$, TNF- $\alpha$, IL-1 $\beta$, and INF- $\gamma$ levels in the supernatant of the bronchoalveolar lavage fluid were evaluated using ELISA kits (Multi science, Hangzhou, Zhejiang, China).

\section{Western blot analysis}

Western blot analysis was used to measure protein expression in the lung tissue. Briefly, a protein lysis buffer was added in the minced lung tissue and homogenized. Then, samples were centrifugated at $12000 \mathrm{rpm}$ and $4^{\circ} \mathrm{C}$. The protein concentrations in the supernatant were quantified using the BCA protein quantification kit (Tiangen, Beijing, China), and subsequently aliquoted into samples. Then, $50 \mu \mathrm{g}$ of protein 


\section{Cellular Physiology Cell Physiol Biochem 2018;47:2396-2406 \\ \begin{tabular}{l|l} 
DOI: 10.1159/000491614 & $\begin{array}{l}\text { O 2018 The Author(s). Published by S. Karger AG, Basel } \\
\text { www.karger.com/cpb }\end{array}$
\end{tabular}}

Cui et al.: A Animal Model of Acute Respiratory Distress Syndrome Induced by White

Smoke Inhalation

was electrophoresed using an 10\% SDS-PAGE and transferred onto a nitrocellulose membrane (BioTrace,

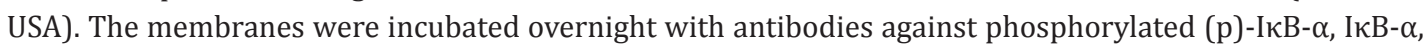
p-p65 NF- $\kappa B$, p65 NF- $\mathrm{B}$, and GAPDH (Cell Signaling Technology, 1:1000 dilution) at $4{ }^{\circ} \mathrm{C}$ on a rotating shaker. Subsequently, the membranes were washed with TBST three times for 5 min each, followed by incubation with horseradish peroxidase-labeled goat anti-rabbit IgG (Beijing ZSGB Bio, 1: 5000 dilution) for $1 \mathrm{~h}$ at $25^{\circ} \mathrm{C}$ on a horizontal shaker. Then, the membranes were washed with TBST twice for 5 min each time, followed by chemiluminescent detection. The protein band areas were quantified using the Image Lab 6.0 software, and the GAPDH antibody was used as the internal reference.

\section{Statistical analysis}

Statistical analyses were performed using the Statistical Package for the Social Sciences (SPSS) v19.0 software (SPSS Inc, Chicago, IL, USA). All data are expressed as mean \pm standard deviation (SD). The data were analyzed using one-way analysis of variance (ANOVA) followed by post-hoc tests of least significant difference (LSD) for multiple pairwise comparisons. A P value $<0.05$ was considered statistically significant.

\section{Results}

\section{Effect of WSI time on the survival rate of rats}

The survival rate of rats after WSI-induced ARDS is shown in Table 1. The results showed that the survival rate of rats in WSI-3 min, WSI-5 min, and WSI-7 min groups decreased gradually. Compared with the survival rate at $0 \mathrm{~h}$ post-WSI, the survival rate of rats at $24 \mathrm{~h}$, $48 \mathrm{~h}$, and $72 \mathrm{~h}$ post-WSI in WSI-3 min group showed no significant reduction; the survival rate of rats showed no significant reduction at $24 \mathrm{~h}$ but had significantly reduced at $48 \mathrm{~h}$ and $72 \mathrm{~h}$ post-WSI in WSI-5 min group; and the survival rate of rats had significantly reduced at $24 \mathrm{~h}, 48 \mathrm{~h}$, and $72 \mathrm{~h}$ post-WSI in the WSI-7 min group.

WSI is associated with histomorphological change in the lung tissue in rats

Histomorphological changes in the lung tissue were evaluated by H\&E staining, and the results are shown in Fig. 2 . At $6 \mathrm{~h}$ and $12 \mathrm{~h}$ post-WSI, lung tissue in the WSI- 3 min and WSI-5 min groups exhibited congestion of airway mucosa, edema, bleeding, and slightly enlarged alveolar space. At $24 \mathrm{~h}$ post-WSI, lung tissue in the WSI-3 min and WSI-5 min groups exhibited neutrophil infiltration and shedding and necrosis of epithelial cells. At 48 $\mathrm{h}$ post-WSI, lung tissue in the WSI-3 min and WSI-5 min groups exhibited alveolar edema and diffuse bleeding. At $72 \mathrm{~h}$ post-WSI, lung tissue in the WSI-5 min group exhibited alveolar wall thickening and alveolar wall collapse, but lung tissue in the WSI-3 min group exhibited decreased edema and reduced neutrophil infiltration. Lung tissue in the WSI-7 min group exhibited neutrophil infiltration, edema, and bleeding at $6 \mathrm{~h}$ and $12 \mathrm{~h}$ post-WSI. With the extension of observation time, lung tissue in the WSI-7 min group exhibited obviously enlarged alveolar space, thinner alveolar septum, and destroyed alveolar walls. The results also showed that the pathological score in WSI-3 min group gradually increased at $6 \mathrm{~h}, 12 \mathrm{~h}$, $24 \mathrm{~h}$, and $48 \mathrm{~h}$ post-WSI, followed by reduction at $72 \mathrm{~h}$ post-WSI; the pathological score in the WSI-5 min and WSI-7 min groups gradually increased at 6 h, 12 h, 24 h, 48 h, and $72 \mathrm{~h}$ post-WSI. Compared with the control group, the pathological score in the WSI-3 min, WSI-

Table 1. Effect of the duration of white smoke inhalation (WSI) on the survival rate of rats. ${ }^{*} \mathrm{P}<0.05$,

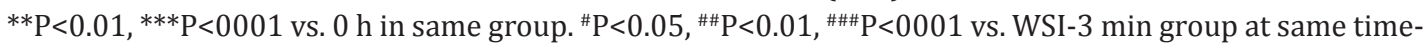
point post-WSI

\begin{tabular}{lccc}
\hline Time post WSI & WSI-3 min & WSI-5 min, & WSI-7 min \\
\hline $0 \mathrm{~h}$ & $100 \%(12 / 12)$ & $100 \%(12 / 12)$ & $100 \%(12 / 12)$ \\
$24 \mathrm{~h}$ & $100 \%(12 / 12)$ & $83.33 \%(10 / 12)$ & $58.33 \%(7 / 12)^{* \#}$ \\
$48 \mathrm{~h}$ & $91.66 \%(11 / 12)$ & $75 \%(8 / 12)^{*}$ & $41.66 \%(5 / 12)^{* * \# \#}$ \\
$72 \mathrm{~h}$ & $83.33 \%(10 / 12)$ & $75 \%(8 / 12)^{*}$ & $25 \%(3 / 12)^{* * * \# \# \#}$ \\
\hline
\end{tabular}




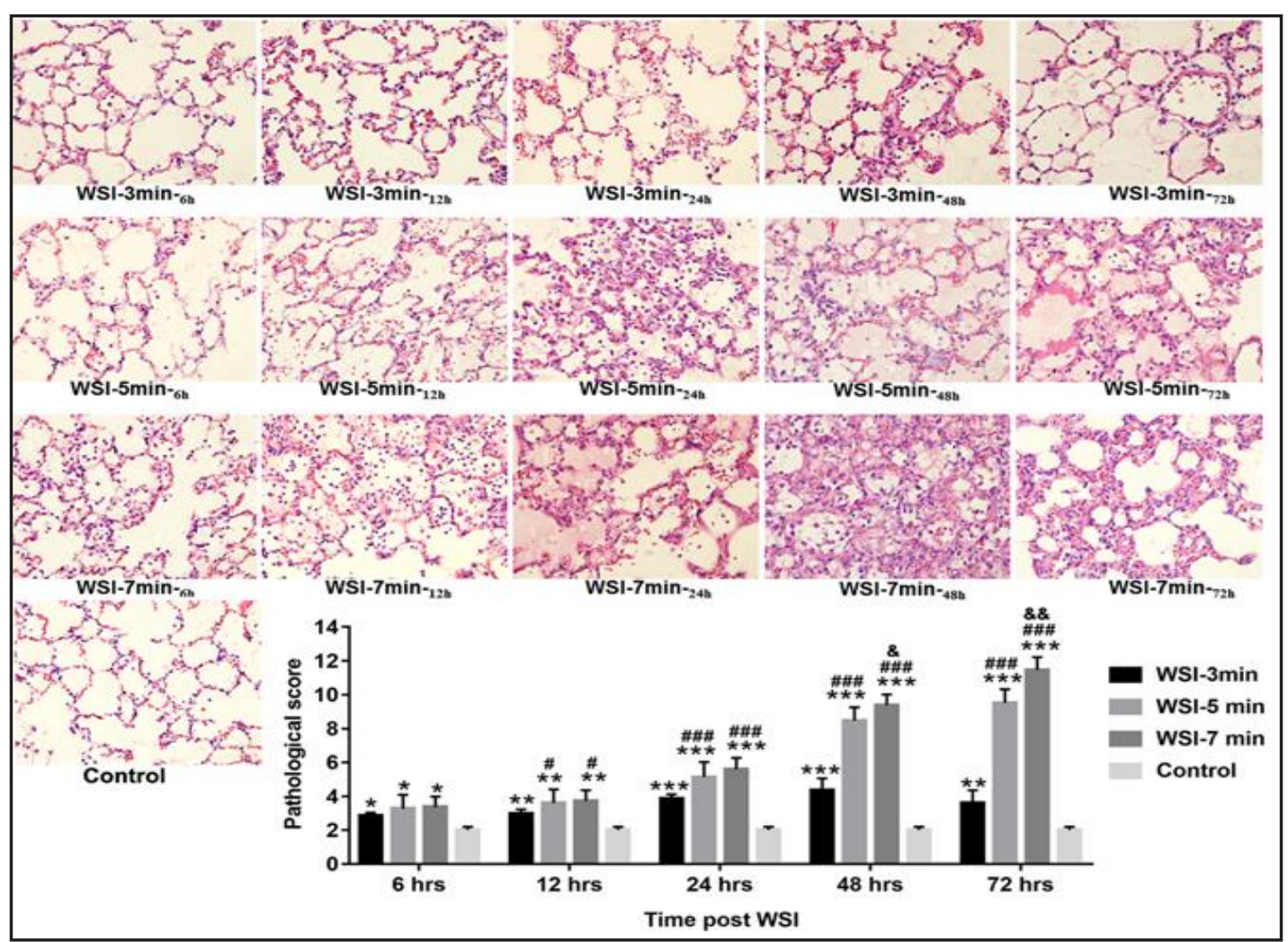

Fig. 2. Histomorphological features of the lung tissue injury due to white smoke inhalation (WSI) were evaluated by Hematoxylin and Eosin staining in the WSI-3 min, WSI-5 min, and WSI-7 min groups at 6 h, 12 $\mathrm{h}, 24 \mathrm{~h}, 48 \mathrm{~h}$, and $72 \mathrm{~h}$ post-WSI and in the control group. The data of the pathological score are represented as mean $\pm \mathrm{SD}$. ${ }^{*} \mathrm{P}<0.05,{ }^{* *} \mathrm{P}<0.01$, and ${ }^{* * *} \mathrm{P}<0.001$ vs. Control. $\# \mathrm{P}<0.05$, \#\#P<0.01, and \#\#\#P<0.001 vs. WSI3 min. $\& \mathrm{P}<0.05$ and $\& \& \mathrm{P}<0.01$ vs. WSI $-5 \mathrm{~min}$.

5 min, and WSI-7 min groups were significantly increased at 6 h, 12 h, 24 h, 48 h, and $72 \mathrm{~h}$ post-WSI $(\mathrm{P}<0.05)$. Compared with the WSI-3 min group, the pathological score in the WSI-5 min and WSI-7 min groups were significantly increased at the same time post-WSI $(\mathrm{P}<0.05)$. Compared with the WSI-5 min group, the CT score in the WSI-7 min group was significantly increased at $48 \mathrm{~h}$ and $72 \mathrm{~h}(\mathrm{P}<0.05)$, but no significant changes were observed at $6 \mathrm{~h}, 12 \mathrm{~h}$, and $24 \mathrm{~h}$ post-WSI $(\mathrm{P}>0.05)$.

WSI is associated with enhanced CT score of lung tissue in rats

Fig. 3 shows the results of the chest CT scan of rats in the normal control group and in the WSI-3 min, WSI-5 min, and WSI-7 min groups after 6 h, 12 h, 24 h, 48 h, and $72 \mathrm{~h}$ after WSI. The results showed that the lung marking, ground-glass opacities, and consolidation of lung in the WSI-3 min, WSI-5 min, and WSI-7 min groups showed different degrees of increase compared with the control group. The results also showed that the CT score in the WSI-3 min group gradually increased at $6 \mathrm{~h}, 12 \mathrm{~h}, 24 \mathrm{~h}$, and $48 \mathrm{~h}$ post-WSI, followed by reduction at $72 \mathrm{~h}$ post-WSI; the CT scores in WSI-5 min and WSI-7 min groups were gradually increased at $6 \mathrm{~h}$, $12 \mathrm{~h}, 24 \mathrm{~h}, 48 \mathrm{~h}$, and $72 \mathrm{~h}$ post-WSI. Compared with control group, the CT score in WSI-3 min, WSI-5 min, and WSI-7 min groups were significantly increased at $6 \mathrm{~h}, 12 \mathrm{~h}, 24 \mathrm{~h}, 48 \mathrm{~h}$, and 72 $\mathrm{h}$ post-WSI $(\mathrm{P}<0.05)$. Compared with the WSI-3 min group, the CT score in WSI-7 min group was significantly increased at the same time post-WSI $(\mathrm{P}<0.001)$, and the CT score in WSI5 min were significantly increased at $24 \mathrm{~h}, 48 \mathrm{~h}$, and $72 \mathrm{~h}(\mathrm{P}<0.001)$ but had no significant changes at $6 \mathrm{~h}$ and $12 \mathrm{~h}$ post-WSI $(\mathrm{P}>0.05)$. Compared with the WSI-5 min group, the CT score in the WSI-7 min group were significantly increased at $6 \mathrm{~h}, 12 \mathrm{~h}$, and $24 \mathrm{~h}(\mathrm{P}<0.001)$, but no significant changes were observed at $48 \mathrm{~h}$ and $72 \mathrm{~h}$ post-WSI $(\mathrm{P}>0.05)$. 


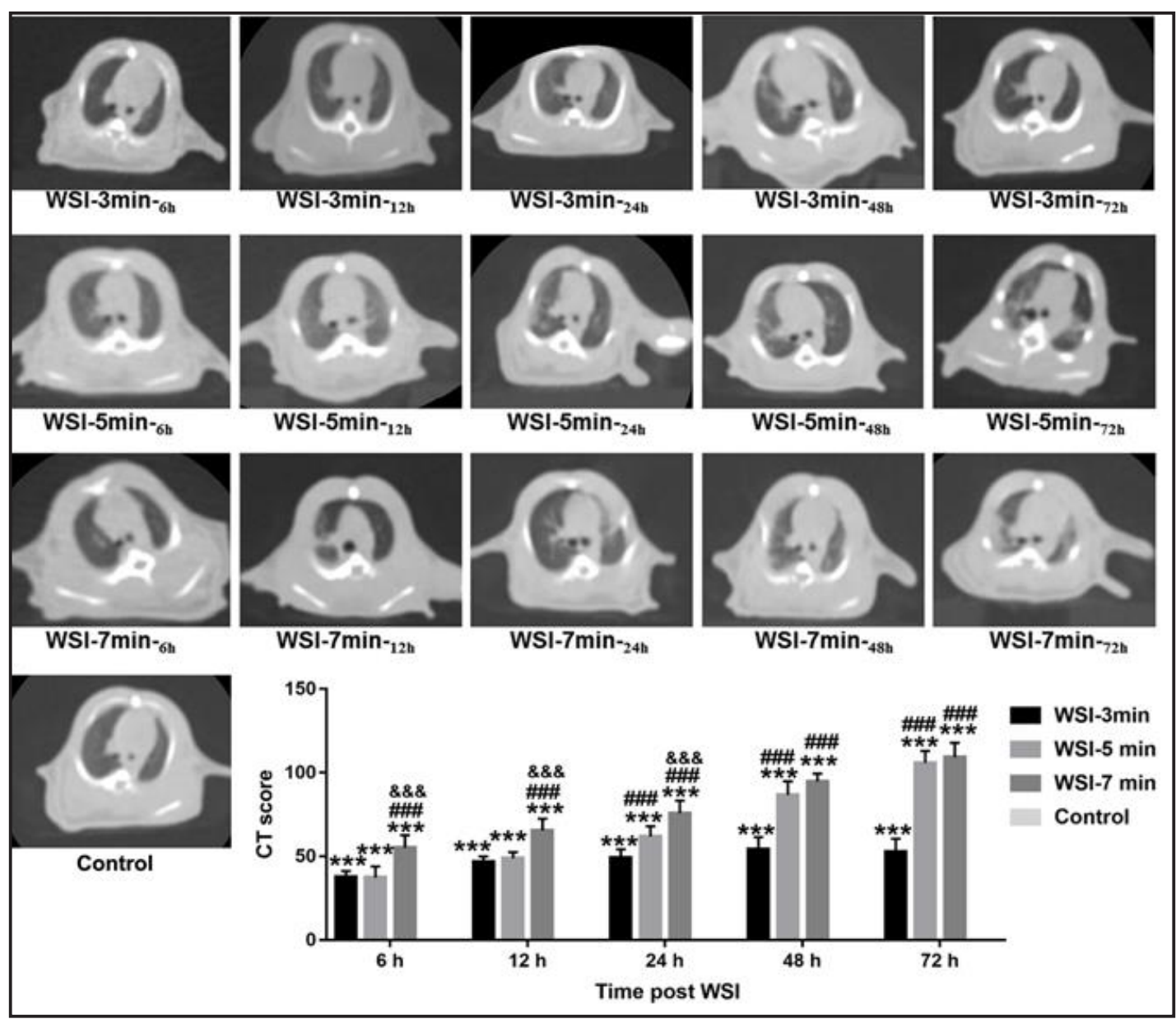

Fig. 3. Lung injury induced by white smoke inhalation (WSI) was tested by CT scan in the WSI- 3 min, WSI-5 min, and WSI-7 min groups at $6 \mathrm{~h}, 12 \mathrm{~h}, 24 \mathrm{~h}, 48 \mathrm{~h}$, and $72 \mathrm{~h}$ post-WSI and in the control group. The data of the CT score were represented as mean $\pm \mathrm{SD}$. The CT score in control group was $0 .{ }^{* * *} \mathrm{P}<0.001$ vs. Control. \#\#\#P<0.001 vs. WSI-3 min. \&\&\&P<0.001 vs. WSI-5 min.

WSI-5 min is associated with changes in arterial blood gas in rats

The results of evaluation of $\mathrm{PaO}_{2}, \mathrm{PaCO}_{2}$, and $\mathrm{PaO}_{2} / \mathrm{FiO}_{2}$ in the control group and at $6 \mathrm{~h}$, $12 \mathrm{~h}, 24 \mathrm{~h}, 48 \mathrm{~h}$, and $72 \mathrm{~h}$ after WSI-5 min are shown in Fig. $4 . \mathrm{PaO}_{2}$ and $\mathrm{PaO}_{2} / \mathrm{FiO}_{2}$ gradually decreased at $6 \mathrm{~h}, 12 \mathrm{~h}, 24 \mathrm{~h}, 48 \mathrm{~h}$, and $72 \mathrm{~h}$ post-WSI- 5 min. The level of PaCO 2 gradually increased at $6 \mathrm{~h}, 12 \mathrm{~h}, 24 \mathrm{~h}$, and $48 \mathrm{~h}$ followed by reduction at $72 \mathrm{~h}$ post-WSI- 5 min. The results also showed that the levels of $\mathrm{PaO}_{2}$ and $\mathrm{PaO} 2 / \mathrm{FiO}_{2}$ were significantly decreased $(\mathrm{P}<0.001)$, while the levels of $\mathrm{PaCO}_{2}$ were significantly increased $(\mathrm{P}<0.01)$ at $6 \mathrm{~h}, 12 \mathrm{~h}, 24 \mathrm{~h}$, $48 \mathrm{~h}$, and $72 \mathrm{~h}$ post-WSI-5 min compared with those in the control group.

\section{WSI-5 min is associated with increased wet/dry weight ratio in rat lung}

Fig. 5 shows the results of evaluation of wet/dry weight ratio in the control group and at $6 \mathrm{~h}, 12 \mathrm{~h}, 24 \mathrm{~h}, 48 \mathrm{~h}$, and $72 \mathrm{~h}$ post-WSI-5 min. Wet/dry weight ratio gradually increased at $6 \mathrm{~h}, 12 \mathrm{~h}, 24 \mathrm{~h}$, and $48 \mathrm{~h}$, followed by reduction at $72 \mathrm{~h}$ post-WSI-5 min, and the wet/dry weight ratio was significantly increased in the WSI-5 min group compared with the control group $(P<0.001)$.

WSI-5 min is associated with increase in the levels of inflammatory cytokines in rats

The levels of TGF- $\beta 1$, TNF- $\alpha$, IL- $1 \beta$, and INF- $\gamma$ in the bronchoalveolar lavage fluid were measured by ELISA (Fig. 6). The results showed that the levels of TGF- $\beta 1$, TNF- $\alpha$, IL- $1 \beta$, KARGER 
Fig. 4. $\mathrm{PaO}_{2}(\mathrm{mmHg}), \mathrm{PaCO}_{2}(\mathrm{mmHg})$, and $\mathrm{PaO}_{2} / \mathrm{FiO}_{2}$ were evaluated at $6 \mathrm{~h}, 12 \mathrm{~h}, 24 \mathrm{~h}, 48 \mathrm{~h}$, and $72 \mathrm{~h}$ in the white smoke inhalation (WSI)-5 min and the control group. Values for $\mathrm{PaO}_{2}(\mathrm{mmHg}), \mathrm{PaCO}_{2}(\mathrm{mmHg})$, and $\mathrm{PaO}_{2} / \mathrm{FiO}_{2}$ are presented as mean $\pm \mathrm{SD}$. ${ }^{* *} \mathrm{P}<0.01$, and $* * * \mathrm{P}<0.001$ vs. Control.

and INF- $\gamma$ were significantly increased at $6 \mathrm{~h}, 12 \mathrm{~h}, 24 \mathrm{~h}, 48 \mathrm{~h}$, and $72 \mathrm{~h}$ post-WSI-5 min compared with the control group $(\mathrm{P}<0.05)$. Additionally, the levels of TGF- $\beta 1$ was gradually increased at $6 \mathrm{~h}, 12 \mathrm{~h}, 24 \mathrm{~h}$, $48 \mathrm{~h}$, and $72 \mathrm{~h}$ post-WSI- 5 min. The levels of TNF- $\alpha$ and IL-1 $\beta$ gradually increased at $6 \mathrm{~h}, 12 \mathrm{~h}, 24 \mathrm{~h}$, followed by reduction at 48 $\mathrm{h}$ and $72 \mathrm{~h}$ post-WSI- $5 \mathrm{~min}$. The levels of INF- $\gamma$ were increased at $6 \mathrm{~h}$, followed by reduction at $12 \mathrm{~h}, 24 \mathrm{~h}, 48 \mathrm{~h}$, and $72 \mathrm{~h}$ postWSI-5 min.

WSI-5 min is associated with activation of the NF- $\kappa B$ signaling pathway in rats

The expression of $p-I \kappa B-\alpha, \quad$ I $\kappa$ B- $\alpha$, p-p65 NF- $\kappa B$, and p65 NF- $\kappa B$ were analyzed by western blotting (Fig. 7). The results showed that the expression of $p-I \kappa B-\alpha$, p-p65 NF- $\kappa B$, and p65 NF- $\kappa B$ were significantly increased at 6 h, 12 h, 24 h, 48 $\mathrm{h}$, and $72 \mathrm{~h}$ post-WSI- 5 min compared with the control group $(\mathrm{P}<0.05)$. Additionally, p-p65 NF- $\kappa$ B and p65 NF- $\kappa$ B were gradually increased at $6 \mathrm{~h}, 12 \mathrm{~h}, 24 \mathrm{~h}, 48 \mathrm{~h}$, and $72 \mathrm{~h}$ post-WSI-5 min. The expression of p-IкB- $\alpha$ gradually increased at $6 \mathrm{~h}, 12 \mathrm{~h}, 24 \mathrm{~h}$, and 48 $\mathrm{h}$, followed by reduction at $72 \mathrm{~h}$ post-WSI-5 min.

\section{Discussion}

WSI is an accidental event, but it may cause ALI, ARDS, and even death. Previous reports on ARDS caused by WSI were mainly based on analysis of clinical cases. However, studies on WSI-induced ARDS using animal models are rare.

In this study, we found that the survival rates of rats in the WSI-3 $\mathrm{min}$, WSI-5 $\mathrm{min}$, and WSI-7 min groups were gradually reduced with the extension of feeding time (at $24 \mathrm{~h}, 48 \mathrm{~h}$, and $72 \mathrm{~h}$ ). The survival rates of rats at $72 \mathrm{~h}$ post-WSI in the WSI-3 min, WSI-5 min, and WSI-7 min groups were
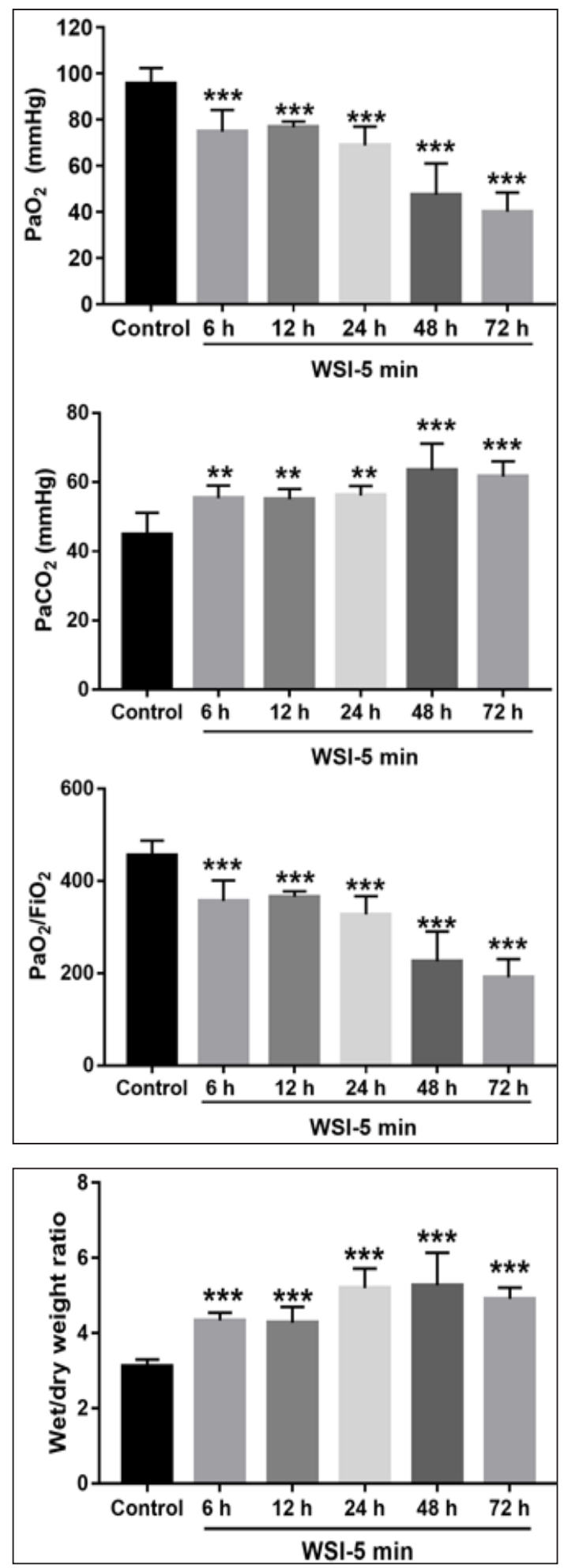

Fig. 5. Wet/dry weight ratio was evaluated in the white smoke inhalation (WSI)-5 min group at $6 \mathrm{~h}, 12$ h, $24 \mathrm{~h}, 48 \mathrm{~h}$, and $72 \mathrm{~h}$ post-WSI and in the control group. Values for wet/dry weight ratio are presented as mean $\pm \mathrm{SD}$. ${ }^{* * *} \mathrm{P}<0.001$ vs. Control. 
Fig. 6. Levels of TGF- $\beta 1$, TNF- $\alpha$, IL- $1 \beta$, and INF- $\gamma$ in the bronchoalveolar lavage fluid were measured by ELISA at $6 \mathrm{~h}, 12 \mathrm{~h}, 24 \mathrm{~h}$, $48 \mathrm{~h}$, and $72 \mathrm{~h}$ in the white smoke inhalation (WSI)-5 min and the control groups. The data are presented as mean $\pm \mathrm{SD}$. $* \mathrm{P}<0.05$, $* * \mathrm{P}<0.01$, and ${ }^{* * *} \mathrm{P}<0.001$ vs. Control.
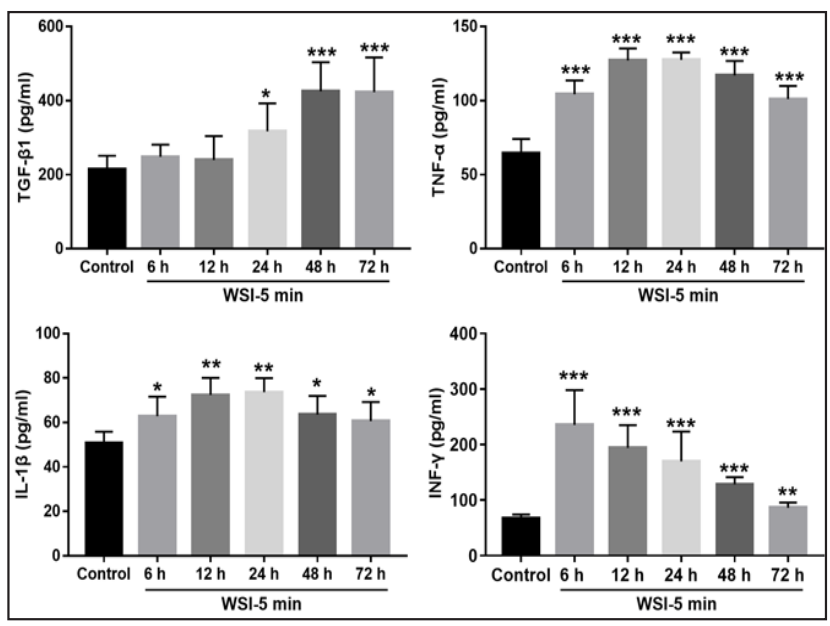

Fig. 7. The expressions of $\mathrm{p}-\mathrm{I} \kappa \mathrm{B}-\alpha, \mathrm{I} \kappa \mathrm{B}-\alpha$, p-p65 NF- $\kappa$ B, and p65 NF- $\kappa$ B were analyzed by western blotting at $6 \mathrm{~h}, 12 \mathrm{~h}, 24 \mathrm{~h}, 48$ $\mathrm{h}$, and $72 \mathrm{~h}$ in the WSI-5 min group. The data are presented as mean $\pm \mathrm{SD}$. ${ }^{*} \mathrm{P}<0.05$, ${ }^{* *} \mathrm{P}<0.01$, and ${ }^{* * *} \mathrm{P}<0.001$ vs. Control.
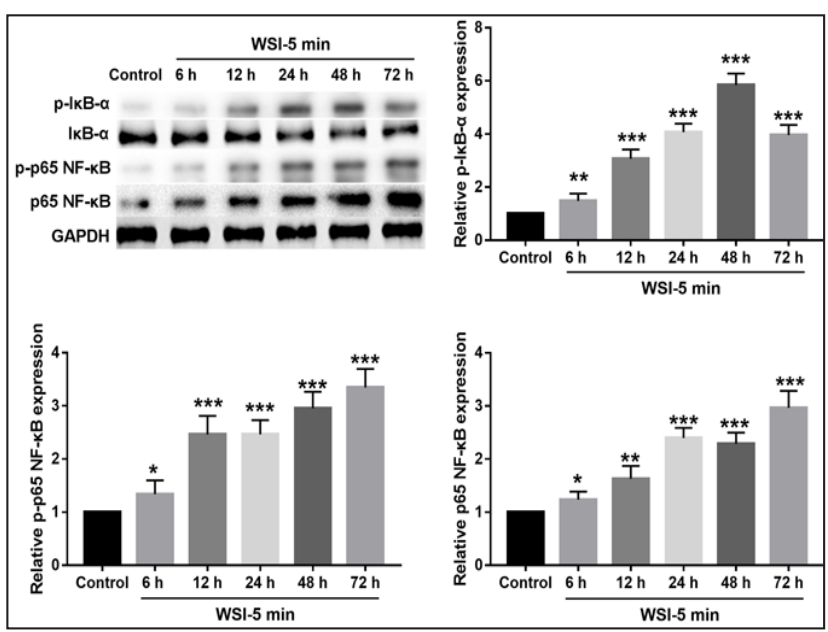

$83.33 \%, 75 \%$, and $25 \%$, respectively. The results suggest that due to the low survival of rats in the WSI-7 min group, further experiment using those rats is impossible; thus, the rats in the WSI-3 min and WSI-5 min groups may be used as a WSI model for further experiments.

In this study, histopathological examination of the lungs of the rats revealed congestion, edema, bleeding, and neutrophil infiltration in the airway mucosa, with alveolar edema and diffuse bleeding, alveolar wall thickening, and alveolar wall collapse post-WSI. The pathological scores gradually increased at $6 \mathrm{~h}, 12 \mathrm{~h}, 24 \mathrm{~h}, 48 \mathrm{~h}$, and $72 \mathrm{~h}$ post-WSI, and all scores were significantly higher than those in normal rats, similar with the pathological characteristics of patients induced by WSI. The pathological characteristics of patients induced by WSI include pulmonary edema, bleeding, inflammatory infiltration, diffuse alveolar damage, and pulmonary fibrosis [15-17]. In our study, the results also revealed that the pathological scores were reduced at $72 \mathrm{~h}$ post-WSI in the WSI-3 min group and were gradually increased after WSI in the WSI-5 min and WSI-7 min groups; the pathological scores in the WSI-5 min and WSI-7 min groups were significantly higher than those in the WSI-3 min group, suggesting that the degree of lung injury increased in a time-dependent manner in the WSI-5 min and the WSI-7 min groups, but the lung injury may have resolved spontaneously at $72 \mathrm{~h}$ post-WSI in the WSI-3 min group. Additionally, the lung marking, ground-glass opacities, and consolidation of lung showed different degrees of increase after WSI. The CT features were similar to the characteristic features of pulmonary vascular lesions in the adult respiratory distress syndrome caused by inhalation of zinc chloride smoke [18]. Similar to the pathological scores, the CT scores also suggest that the degree of lung injury was increased in a time-dependent manner in the WSI-5 min and WSI-7 min groups, but the 


\section{Cellular Physiology Cell Physiol Biochem 2018;47:2396-2406 \\ \begin{tabular}{l|l} 
DOI: 10.1159/000491614 & $\begin{array}{l}\text { O } 2018 \text { The Author(s). Published by S. Karger AG, Basel } \\
\text { www.karger.com/cpb }\end{array}$
\end{tabular}}

Cui et al.: A Animal Model of Acute Respiratory Distress Syndrome Induced by White

Smoke Inhalation

lung injury may have spontaneously resolved at $72 \mathrm{~h}$ post-WSI in the WSI-3 min group. The results of $\mathrm{H} \& \mathrm{E}$ staining and CT scanning suggest that the pathological changes in the rats in the WSI-5 min and WSI-7 min groups are very similar to those observed in humans and can simulate the pathological changes in patients with lung injury induced by WSI. But the lung injury may have spontaneously resolved at $72 \mathrm{~h}$ post-WSI in the WSI-3 min group, so the rats of the WSI-3 min group can not be used as WSI models. Thus, based on our study results obtained by evaluation of the survival rate, H\&E staining, and CT scan, the rats of the WSI-5 min group can be used as WSI models for further experiments.

The $\mathrm{PaO}_{2}$ and $\mathrm{PaO} 2 / \mathrm{FiO}_{2}$ were significantly decreased $(\mathrm{P}<0.001)$ while $\mathrm{PaCO}_{2}$ was significantly increased $(\mathrm{P}<0.01)$ in the WSI-5 min group compared with the control group, suggesting that the rats in the WSI- 5 min group develop respiratory insufficiency, which is exacerbated in a time-dependent manner. Additionally, we found that the wet/dry weight ratio gradually increased in the WSI-5 min group, and it was significantly increased compared with control group, suggesting that the degree of pulmonary edema increased in the WSI-5 min group in a time-dependent manner. This finding is similar to the findings of previous studies that showed the degree of pulmonary edema was increased after smoke inhalation in ovine model [19]. The results of the evaluation of arterial blood gas levels and lung wet/ dry weight ratio further indicate that the pathological changes in the rat form the WSI-5 min group are very similar to those in humans and can simulate the pathological changes in patients with lung injury induced by WSI.

To identify the potential mechanisms underlying the effects of WSI, the levels of TGF- $\beta 1$, TNF- $\alpha$, IL-1 $\beta$, and INF- $\gamma$ in the bronchoalveolar lavage fluid and the expression of $p-I \kappa B-\alpha$,

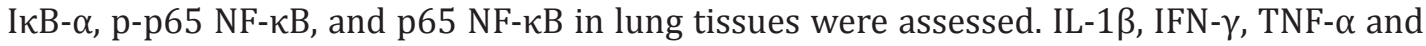
TGF- $\beta 1$ levels were closely related to lung injury, inhibiting those expression can reduce lung injury [20]. TGF- $\beta 1$ after acute respiratory distress syndrome can regulate lung injury repair, especially the regulation of repair in pulmonary fibrosis in the advanced stages of the disease $[21,22]$. TNF- $\alpha$ activates the inflammatory response and plays an important role in lung injury [23]. TGF- $\beta 1$ and TNF- $\alpha$ levels were reported to be increased after WSI during military training [24]. IL-1 $\beta$ suppresses cigarette smoke-induced pulmonary inflammation in mice [25]. In the early stage of ARDS, IL-1 $\beta$ expression was enhanced and promoted alveolar epithelial repair [26]. The results showed that the levels of TGF- $\beta 1$, TNF- $\alpha$, IL- $1 \beta$, and INF- $\gamma$ were significantly increased in the WSI-5 min group compared with the control group, suggesting that early inflammatory cytokines were rapidly produced in response to WSI. $\mathrm{NF}-\kappa \mathrm{B}$, an important nuclear transcription factor, were activated by various inflammatory cytokines such as TGF- $\beta 1$, TNF- $\alpha$, and IL- $1 \beta$. NF- $\kappa$ B activation can in turn promote the expression of inflammatory cytokines such as INF- $\gamma$, TGF- $\beta 1$, TNF- $\alpha$, and IL-1 $\beta[27,28]$. A previous study showed that NF- $\kappa B$ activation occurred in the lungs of patients with ARDS and may contribute to the increased expression of immunoregulatory cytokines and other proinflammatory cytokines [29]. NF- $\kappa \mathrm{B}$ activation promotes cigarette smoke -induced lung inflammation and airway epithelial cell apoptosis [30]. In this study, we found that the expressions of p-IкB- $\alpha$, p-p65 NF- $\kappa \mathrm{B}$, and p65 NF- $\kappa \mathrm{B}$ were significantly increased at $6 \mathrm{~h}, 12$ $\mathrm{h}, 24 \mathrm{~h}, 48 \mathrm{~h}$, and $72 \mathrm{~h}$ in the WSI-5 min group compared with the control group. These results suggest that the NF- $\kappa B$ signaling pathway was activated by WSI, which may promote the expression of INF- $\gamma$, TGF- $\beta 1$, TNF- $\alpha$, and IL- $1 \beta$, increasing the severity of lung injury. Thus, the NF- $\kappa \mathrm{B}$ signaling pathway may be a potential therapeutic target for the treatment of WSI-induced ARDS.

In conclusion, we found that the pathological changes in the rat model of WSI-5 min are very similar to those in patients with ARDS induced by WSI. Additionally, the NF- $\kappa B$ signaling pathway was activated by WSI, which may promote the expression of INF- $\gamma$, TGF- $\beta 1$, TNF- $\alpha$, and IL-1 $\beta$. Thus, the NF- $\mathrm{KB}$ signaling pathway may be a potential therapeutic target for the treatment of WSI-induced ARDS. The rats in the WSI-5 min group can be used as the WSIinduced ALI models for further experiments. 


\section{Cellular Physiology Cell Physiol Biochem 2018;47:2396-2406

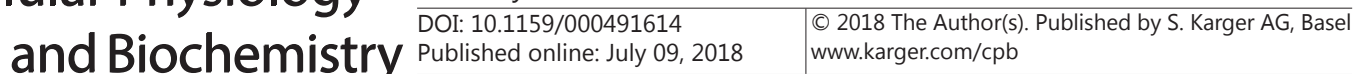 \\ Cui et al.: A Animal Model of Acute Respiratory Distress Syndrome Induced by White Smoke Inhalation}

\section{Acknowledgements}

This work was supported by grants from the Academician Workstation Program, the Lijiang Scholars Program, Guilin science and technology project (NO.: 20170109-35), and Guangxi science and technology project (NO.: 1140003A-39).

\section{Disclosure Statement}

The authors who have taken part in this study declare that they have no conflicts of interest with respect to this paper.

\section{References}

1 Cullumbine H: The toxicity of screening smokes. J R Army Med Corps 1957;103:119-122.

2 Antonio AC, Castro PS, Freire LO: Smoke inhalation injury during enclosed-space fires: An update. J Bras Pneumol 2013;39:373-381.

3 Chian CF, Wu CP, Chen CW, Su WL, Yeh CB, Perng WC: Acute respiratory distress syndrome after zinc chloride inahalation: Survival after extracorporeal life support and corticosteroid treatment. Am J Crit Care 2010;19:86-90.

-4 Gil F, Pla A, Hernandez AF, Mercado JM, Mendez F: A fatal case following exposure to zinc chloride and hexachloroethane from a smoke bomb in a fire simulation at a school. Clin Toxicol 2008;46:563-565.

5 Cao L, Zhang XG, Wang JG, Wang HB, Chen YB, Zhao DH, Shi WF, Xie LX: Pulmonary function test findings in patients with acute inhalation injury caused by smoke bombs. J Thorac Dis 2016;8:3160-3167.

-6 Schaeffer DJ, Kapila S, Meadows JE, Hinderberger E, Wentsel R: Chemical characterization of residues from military hc smokepots. Journal of Hazardous Materials 1988;17:315-328.

-7 Jarvis A: The combustion reactions of a pyrotechnic white smoke composition. Combustion and Flame 1970;14:313-320.

-8 Tan SX, Jiang DX, Hu RC, Dai AG, Gan GX, Fu DY, Kong CC, Chen YR, Wang LL, Li J: Endoplasmic reticulum stress induces hrd1 to protect alveolar type ii epithelial cells from apoptosis induced by cigarette smoke extract. Cell Physiol Biochem 2017;43:1337-1345.

-9 Nemmar A, Al-Salam S, Yuvaraju P, Beegam S, Yasin J, Ali BH: Chronic exposure to water-pipe smoke induces alveolar enlargement, DNA damage and impairment of lung function. Cell Physiol Biochem 2016;38:982-992.

10 Brown RF, Marrs TC, Rice P, Masek LC: The histopathology of rat lung following exposure to zinc oxide/ hexachloroethane smoke or installation with zinc chloride followed by treatment with $70 \%$ oxygen. Environ Health Perspect 1990;85:81-87.

11 Hsu HH, Tzao C, Chang WC, Wu CP, Tung HJ, Chen CY, Perng WC: Zinc chloride (smoke bomb) inhalation lung injury: Clinical presentations, high-resolution ct findings, and pulmonary function test results. Chest 2005;127:2064-2071.

12 Xie F, Zhang X, Xie L: Prognostic value of serum zinc levels in patients with acute hc/zinc chloride smoke inhalation. Medicine 2017;96:e8156.

$>13$ Cheng W, Ran Z, Wei L, La-na D, Xiao-zhuo Z, Yan-hua R, Fang-gang N, Guo-an Z: Pathological changes of the three clinical types of laryngeal burns based on a canine model. Burns 2014;40:257-267.

14 Park MS, Cancio LC, Batchinsky AI, McCarthy MJ, Jordan BS, Brinkley WW, Dubick MA, Goodwin CW: Assessment of severity of ovine smoke inhalation injury by analysis of computed tomographic scans. J Trauma 2003;55:417-427.

15 Loh CH, Liou SH, Chang YW, Chen HI, Perng WC, Ku HY, Chen YH: Hepatic injuries of hexachloroethane smoke inhalation: The first analytical epidemiological study. Toxicology 2008;247:119-122.

16 Rehberg S, Maybauer MO, Enkhbaatar P, Maybauer DM, Yamamoto Y, Traber DL: Pathophysiology, management and treatment of smoke inhalation injury. Expert Rev Respir Med 2009;3:283-297.

17 Chatzivasiloglou F, Katsenos S, Psara A, Tsintiris K: Orange-pigmented sputum as a manifestation of smoke grenade inhalation injury. J Bronchology Interv Pulmonol 2016;23:76-78. 


\section{Cellular Physiology Cell Physiol Biochem 2018;47:2396-2406 \begin{tabular}{l|l} 
DOI: 10.1159/000491614 & $\begin{array}{l}\text { O } 2018 \text { The Author(s). Published by S. Karger AG, Basel } \\
\text { www.karger.com/cpb }\end{array}$
\end{tabular}}

Cui et al.: A Animal Model of Acute Respiratory Distress Syndrome Induced by White

18 Homma S, Jones R, Qvist J, Zapol WM, Reid L: Pulmonary vascular lesions in the adult respiratory distress syndrome caused by inhalation of zinc chloride smoke: A morphometric study. Hum Pathol 1992;23:45-50.

19 Nakazawa H, Gustafsson TO, Traber LD, Herndon DN, Traber DL: Alpha-trinositol decreases lung edema formation after smoke inhalation in an ovine model. J Appl Physiol 1985;76:278-282.

20 Wang C, Ding H, Tang X, Li Z, Gan L: Effect of liuweibuqi capsules in pulmonary alveolar epithelial cells and copd through jak/stat pathway. Cell Physiol Biochem 2017;43:743-756.

21 Ko JW, Shin NR, Park SH, Lee IC, Ryu JM, Kim HJ, Cho YK, Kim JC, Shin IS: Silibinin inhibits the fibrotic responses induced by cigarette smoke via suppression of tgf-beta1/smad 2/3 signaling. Food Chem Toxicol 2017;106:424-429.

22 Ko JW, Shin NR, Park SH, Kim JS, Cho YK, Kim JC, Shin IS, Shin DH: Pine bark extract (pycnogenol(r)) suppresses cigarette smoke-induced fibrotic response via transforming growth factor-beta1/smad family member 2/3 signaling. Lab Anim Res 2017;33:76-83.

23 Jia R, Zhang H, Yang Z, Zhao H, Liu F, Wang H, Miao M, Wang Q, Liu Y: Protective effects of schisandrin b on cigarette smoke-induced airway injury in mice through nrf2 pathway. Int Immunopharmacol 2017;53:1116.

24 Huang KL, Chen CW, Chu SJ, Perng WC, Wu CP: Systemic inflammation caused by white smoke inhalation in a combat exercise. Chest 2008;133:722-728.

25 Bucher H, Mang S, Keck M, Przibilla M, Lamb DJ, Schiele F, Wittenbrink M, Fuchs K, Jung B, Erb KJ, Peter D: Neutralization of both il-1alpha/il-1beta plays a major role in suppressing combined cigarette smoke/ virus-induced pulmonary inflammation in mice. Pulm Pharmacol Ther 2017;44:96-105.

26 Geiser T, Atabai K, Jarreau PH, Ware LB, Pugin J, Matthay MA: Pulmonary edema fluid from patients with acute lung injury augments in vitro alveolar epithelial repair by an il-1beta-dependent mechanism. Am J Respir Crit Care Med 2001;163:1384-1388.

-27 Gleason CE, Ordureau A, Gourlay R, Arthur JS, Cohen P: Polyubiquitin binding to optineurin is required for optimal activation of tank-binding kinase 1 and production of interferon beta. J Biol Chem 2011;286:35663-35674.

28 Wang P, Han X, Mo B, Huang G, Wang C: Lps enhances tlr4 expression and ifngamma production via the tlr4/irak/nfkappab signaling pathway in rat pulmonary arterial smooth muscle cells. Mol Med Rep 2017;16:3111-3116.

29 Moine P, McIntyre R, Schwartz MD, Kaneko D, Shenkar R, Le Tulzo Y, Moore EE, Abraham E: Nf-kappab regulatory mechanisms in alveolar macrophages from patients with acute respiratory distress syndrome. Shock 2000;13:85-91.

-30 Xue H, Li MX: Microrna-150 protects against cigarette smoke-induced lung inflammation and airway epithelial cell apoptosis through repressing p53: Microrna-150 in cs-induced lung inflammation. Hum Exp Toxicol 2017;1:960327117741749. 